\title{
A Learning Innovation Model for Increasing Workers Competencies in Industrial Factories in Three Southernmost Provinces of Thailand
}

\author{
Anuchit Ngamkajonviwat, Wasant Atisabda, Ophat Kaosaiyaporn, and Chidchanok Choengchao
}

\begin{abstract}
This study was to develop a Learning Innovation Model to increase workers' competencies in working performance and the quality of life. General data was collected from four groups of respondents: provincial labor administrators, factory administrators, workers, and educators. The quantitative data was analyzed and followed by the qualitative data analysis through the focus group which indicated four perspectives in labor management. Those were the working performance, the life skills, the sufficiency economics, and the multicultural awareness which were the essential factors for worker development. A Learning Innovation Model for increasing workers' competencies in industrial factories in three southernmost provinces of Thailand was proposed based on the hybrid learning.
\end{abstract}

Index Terms-Learning innovation model, workers, competencies, three southernmost provinces of Thailand.

\section{INTRODUCTION}

The industrial sector is considered as a factor to mobilize the economics of the country. Although the industrial sectors play major roles in the last period of economic development, in the current days so far they tend to be very influential. The industrial sectors are developed rapidly with an increase of products utilizing the modern technology. It increases the productivity and the quantity of exports. Yet, to level up workers' quality is also crucial. The framework of industrial sectors, thus, has been rearranged in order to support the workers having higher educational qualifications both in public and private sections. This provides benefits for workers and companies to get readiness in the world market competition.

One of major problems which workers currently encounter is the lack of knowledge of their own rights. This problem is rooted from workers' low level of education. It is reported that around $80 \%$ of unskilled workers are illiterate. Therefore, those workers' voices have been ignored, and they have rarely chances to negotiate their earnings and rights. Some employers just take advantages from these gaps. The government has attempted to solve this problem by including the issue of worker development in the National Economic and Social Development Plan. The plan has focused on workers' educational supporting and practical training

Manuscript received April 17, 2014; revised June 17, 2014. This work was supported in part by Prince of Songkla University.

The authors are with the Department of Educational Technology and Department of Educational Research and Evaluation, Faculty of Education, Prince of Songkla University, Thailand (e-mail: anuchit.ng@hotmail.com, vassan.a@psu.ac.th,ophat.k@psu.ac.th, cchitcha@bunga.psu.ac.th). especially on their rights and duties written in constitution and labor laws. Not only that, the government also supports workers' education in several ways. For example, promote educational institutions to play roles in companies by providing workers knowledge in order to fulfill educational gaps among workers

Thailand is dominated by Buddhists. It is around $80 \%$ of the population. However, in the three southernmost provinces of Thailand Muslim is the majority which is around $80 \%$, while the others are Buddhist Thai and Chinese. Thus, this area is the land of cultural diversity. Multicultural education is one of the main issues which are raised to study to make people more realize in cultural diversity [1]. Anyway, the three southern most areas is the sensitive area with the unrest situation of Muslim separatist [2]. The government has paid special attention to the local economic development to solve these problems [3]. There are many projects established in the area in order to support the quality of life as well as the economic development based on the fishery, the rubber plantation, the fruit plantation, and the related industry and commerce. Likely, the Free Trade aims to integrate the local economic and social contexts with the whole country economic system and society. Also, this project develops the international connections, disperse income among society, and better the well-being of Thai local people. In other words, these policies influence the skilled workers to be more required in this multicultural context. Moreover, King Bhumibol's Initiative of Sufficiency Economy Project has been promoted all over the country. "Sufficiency Economy" is a philosophy that stresses the middle path as an overriding principle for appropriate conduct by the populace at all levels. This applies to conduct starting from the level of the families, communities, as well as the level of nation in development and administration so as to modernize in line with the forces of globalization. "Sufficiency" means moderation, reasonableness, and the need of self-immunity for sufficient protection from impact arising from internal and external changes. To achieve this, an application of knowledge with due consideration and prudence is essential. In particular great care is needed in the utilization of theories and methodologies for planning and implementation in every step. The Sufficiency Economy Project has also been promoted in three southern most provinces of Pattani, Yala, and Narathiwas. The farmers in the rural area as well as the workers in the cities have applied the Sufficiency Economy Philosophy in their lives which aims to sustain their quality of life and high value base. They need to realize the Sufficiency Economy which stresses the middle path as an overriding principle for appropriate conduct by the populace at all levels. 
This applies to conduct starting from the level of the families, communities, as well as the level of nation in development and administration so as to modernize in line with the forces of globalization. "Sufficiency" means moderation, reasonableness, and the need of self-immunity for sufficient protection from impact arising from internal and external changes [4], [5]. To achieve this, an application of knowledge with due consideration and prudence is essential. In particular great care is needed in the utilization of theories and methodologies for planning and implementation in every step. At the same time, it is essential to strengthen the moral fiber of the nation, so that everyone, particularly public officials, academics, businessmen at all levels, adheres first and foremost to the principles of honesty and integrity. In addition, a way of life based on patience, perseverance, diligence, wisdom and prudence is indispensable to create balance and be able to cope appropriately with critical challenges arising from extensive and rapid socioeconomic, environmental, and cultural changes in the world.

Technology is an important tool to support self-directed learning and creating the new learning environment for the workers [6]-[8].

This study is designed to support and increase the working competencies and the quality of lives of workers and people who live and work in the factories in the sensitive areas of the southernmost provinces of Thailand.

\section{OBJECTIVE}

1) To study a fundamental information and knowledge related to the increase of workers' competencies under multicultural society and sufficiency economy in order to upgrade the life quality of workers in industrial factories in three most southern provinces of Thailand;

2) To develop a model of learning innovation to increase the workers' competencies under multicultural society and sufficiency economy in order to upgrade the life quality of workers in industrial factories in three southernmost provinces of Thailand;

3) To propose a model of learning innovation to increase the workers' competencies under multicultural society and sufficiency economy in order to upgrade the life quality of workers in industrial factories in three southernmost provinces of Thailand.

\section{Methodology of StUdey}

Step I: The fundamental information was studied. It included:

1) The related literature was reviewed;

2) The in-depth interviews with experts in education, cultural diversity, multicultural education, and sufficiency economy in the visions of learning innovation model to increase workers' competencies, the issues of cultural diversity and sufficiency economy, and problems in promoting learning for workers,

3) The in-depth interview with provincial administrators, industrial factory administrators, and representatives from workers' development agency,

4) The questionnaires were distributed to workers in the industrial factories in three southernmost provinces of Thailand.

\section{Step II:}

1) The focus group discussion of educators, entrepreneurs, industry and labor related government officers were organized to set a framework of a Learning Innovation Model.

2) A Prototype of Learning Innovation Model for increasing worker competencies in industrial factories in three southernmost provinces of Thailand was proposed.

3) Final approval of a Learning Innovation Model for increasing workers competencies in industrial factories in three southernmost provinces of Thailand. It was approved by the experts including three labor development specialists and three human resources development specialists.

\section{FINDING}

From the literature reviews, the application of adult learning notions was proposed to based on five fundamentals of educational management are identified as following:

1) Needs and interests. Workers tend to learn effectively as the knowledge to be learned matches with their wants, interests, and their prior experiences. As a result, the motivation of workers should be priority consideration in educational management.

2) Situations and events related to workers' life and experiences. The main objective of educational set up for workers should consider the situation and events related to their lives. Also, the contents should be associated with workers' experiences.

3) Working experience analysis. Experiences are the most valuable sources of knowledge for workers. Workers tend to critically think of their experiences that can be shared and exchanged with others and then find out its applications.

4) Adult workers liked to control of their selves. Workers should have maturity and capacity enough.

5) Individual difference. The more ages of workers, the individual difference will much more increase. Thus, to set up education for workers should consider these issues: places, times, and topics which may be varied depended on workers' competency and professional field.

It is congruent with Malcolm Knowles's andragogy and self-directed learning which identifies (1980) the six principles of adult learning outlined: 1) adults are internally motivated and self-directed, 2) adults bring life experiences and knowledge to learning experiences, 3) adults are goal oriented, 4) adults are relevancy oriented, 5) adults are practical, and 6) adult learners like to be respected.

In Fig. 1 the training module was developed based on the competency-based curriculum development for the adult or worker learners. Training material should be sufficient and well prepared and suitable for workers' self-study as well as workshop, such as working equipment, handout, exercise worksheet, programmed text, training package, computer-based courseware, training curriculum, etc. Various types of training delivery should be implemented and organized effectively based on andragogy as well as the 
assessment tools should be valid in terms of their types and reliable.

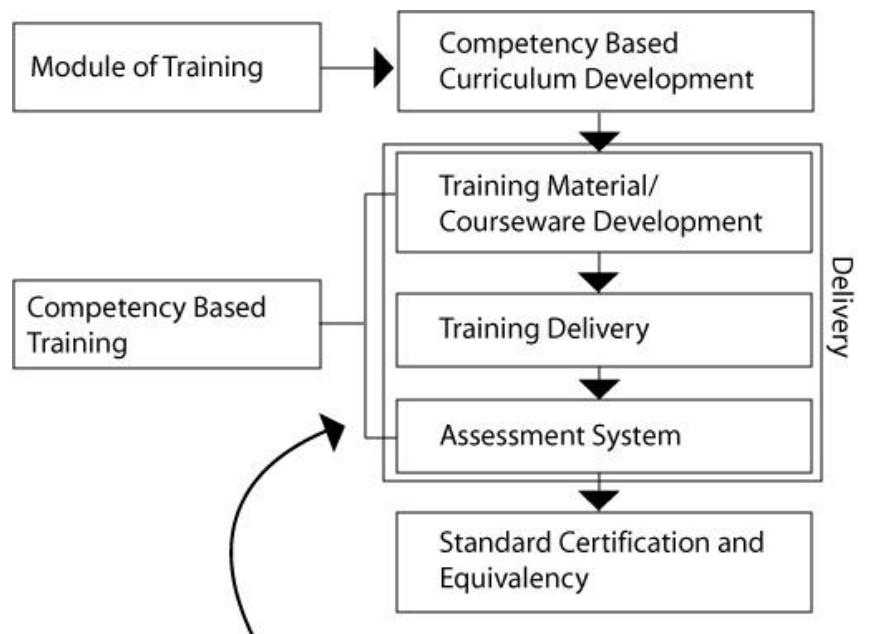

Component of competency development

Fig. 1. Model of competency-based training (CBT) [9].

In applying competency-based training, the elements mentioned above are necessarily adjusted and well-prepared. They are including tools, equipment, training materials, assessment tools, assessed criteria, and professional trainers.. The training packages will cover the technical aspects for working as well as life-experiences modules, such as multicultural issues and sufficiency economy concepts. By doing this, the training packages are already analyzed, well designed, and identified the module of training by experts of each field.

\section{A Proposed LEARNING INNOVATION MODEL}

From the quantitative and qualitative study, a learning innovation model was developed to increase workers competencies in working and living in multicultural society [10] and to follow the principles of adult learning and self-directed learning, and sufficiency economy in order to enhance worker quality of lives in industrial sectors in three southernmost provinces.

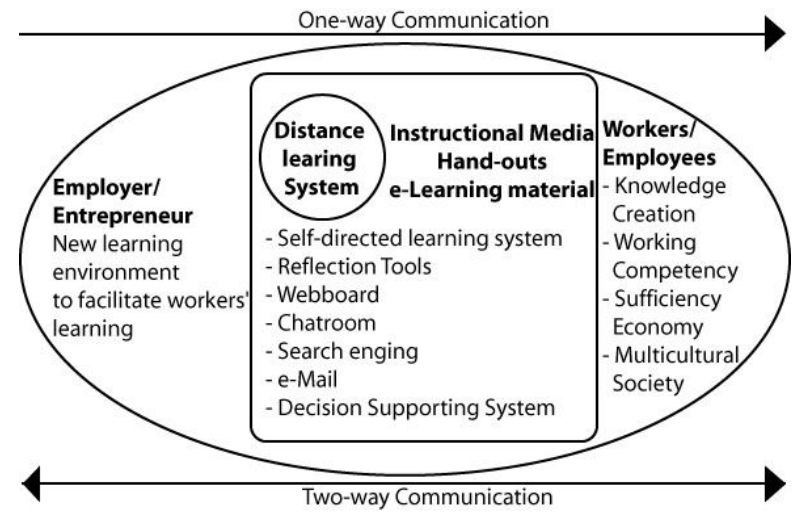

Fig. 2. A proposed learning innovation model for increasing workers competencies in working and living in multicultural society and sufficiency economy.

In Fig. 2 the employer or entrepreneur initiated the policy and practices to create the new learning environment to facilitate workers' learning based on the andragogy which is instructional strategies developed for adult learners. It is the art and science to teach adult to learn it can be interpret as the process of engaging adult learners with new learning experiences. Technology innovations can increase the access and efficiency in learning more and enhance adult learner's interaction. They can overcome the challenges and bring more opportunities in learning. The synchronous and asynchronous learning can facilitate workers to develop their work and life skills. The training facilities in workplaces were proposed. They included the library with computer facilities to enhance training and learning. As most of workers were full-time employees, it was very hard for them to have special education during day time. Therefore, it was necessary to have the distance learning facilities to support workers' learning at home. However, all workers needed to be trained to be a self-directed learner.

\section{A LEARNING INNOVATION MODEL}

\begin{tabular}{|c|c|c|c|}
\hline \multicolumn{2}{|c|}{$\begin{array}{l}\text { Learning through the new learning } \\
\text { environment with blended learning }\end{array}$} & \multicolumn{2}{|c|}{$\begin{array}{l}\text { Lead and facilitate workers to live } \\
\text { under the philosophy of sufficiency } \\
\text { economy through the new learning }\end{array}$} \\
\hline \begin{tabular}{|l|} 
Employer \\
Knowledge \\
Creation \\
- Facility Support \\
- Resource Support
\end{tabular} & $\begin{array}{l}\text { Workers } \\
\text { Facilities } \\
\text { - Library } \\
\text { - Computer } \\
\text { Room }\end{array}$ & \begin{tabular}{|l|} 
Employer \\
Sufficiency \\
Economy \\
- Facility Support \\
- Resource Support
\end{tabular} & \begin{tabular}{|l} 
Workers \\
Facilities \\
- Library \\
- Computer \\
Room
\end{tabular} \\
\hline \multicolumn{4}{|c|}{$\begin{array}{l}\text { Learning Innovation for Increasing competence in work performance } \\
\text { and Life Skills in Multicultural and Sufficient economy to improve Life } \\
\text { Quality of worker industrial factory in Most South province of Thailand }\end{array}$} \\
\hline \multicolumn{2}{|c|}{$\begin{array}{l}\text { Development of workers' } \\
\text { competencies including working } \\
\text { as well as life skills under the new } \\
\text { learning environment with blended } \\
\text { learning }\end{array}$} & \multicolumn{2}{|c|}{$\begin{array}{l}\text { Quality of life development under } \\
\text { multicultural society }\end{array}$} \\
\hline \begin{tabular}{|l|} 
Employer \\
Working \\
Competencies \\
- Working \\
competency \\
development \\
- Working resource \\
support
\end{tabular} & \begin{tabular}{l||} 
Workers \\
- Working skill \\
development \\
- Self-directed \\
learning
\end{tabular} & \begin{tabular}{|l|} 
Employer \\
Multicultural \\
society \\
- Non discrimination \\
based on race or \\
religious \\
- Promotion of \\
cultural diversity
\end{tabular} & $\begin{array}{l}\text { Workers } \\
\text { - Working skill } \\
\text { development } \\
\text { - Self-directed } \\
\text { learning }\end{array}$ \\
\hline \multicolumn{4}{|c|}{ Worker Facilities Learning Support } \\
\hline \multicolumn{2}{|c|}{$\begin{array}{l}\text { Workers Communications Tools } \\
\text { - e-Mail } \\
\text { - Chatroom } \\
\text { - Webboard }\end{array}$} & \multicolumn{2}{|c|}{$\begin{array}{l}\text { Workers Communications Tools } \\
\text { - Training delivery/ materials } \\
\text { - Reflection room } \\
\text { - Knowledge management tools } \\
\text { - Search engine } \\
\text { - Resource Support }\end{array}$} \\
\hline
\end{tabular}

Fig. 3 the focus group discussion of experts revealed a learning innovation model for increasing workers competencies in working and living in multicultural society and the sufficiency economy to enhance worker quality of lives in industrial sectors in three southernmost provinces. The blended learning was introduced. It included the employer or entrepreneur's initiation to create the new learning environment to facilitate on the job training in both working competencies and workers' life quality

The human resource development for workers included the in-house training and the distance learning at home. The 
face-to-face training approaches as well as the workshop will be organized in the plant. At home the workers can develop their skills and knowledge through the self-directed learning system which includes the web-based training system, the reflection tool, the web board and chat room, the communication tools, etc.. For workers who do not have technology facilities at home they can access to these facilities at the plant or the adult learning facility.

\section{CONCLUSION AND DISCUSSION}

The new roles of employee or entrepreneur are to initiate and support the new learning environment in workplace. The plant is not only for working, but also for learning to have better life. Traditional face-to-face on the job training along with technology-based training should be implemented in worker development. The King's project of Sufficiency economy will be integrated in workers' lives. As this southernmost area is dominated by Thai Muslims and Thai Buddhists and Chinese are minority. They should be supported to live and learn in multicultural society.

\section{REFERENCES}

[1] B. Yonyuan et al., "A Survey of respect for cultural diversity among teachers in three southern border provinces, Thailand," Journal of Social Sciences and Humanities, vol. 16, no. 5, pp. 741-758, 2010.

[2] B. Yonyuan. (2008). Promotion of children development in the context of cultural diversity. [Online]. Available: http://www.cf. mahidol.ac.th/autopage/file/ WedJuly2008-22-18-5-4articel-004.pdf

[3] B. Fahrungsang, K. Uttayawalee, and E. Sungthong, Collection of Multicutural education knowledge in the southernmost of Thailand, Pattani: Prince of Songkla University, 2006.

[4] T. Wattanasupachoke, "Sufficiency economy principles: applications for organisation management strategy," Journal of American Academy of Business, Cambridge, vol. 14, no. 2, pp. 263-270, 2009.

[5] G. Ruenrom, "Applying the philosphy of sufficiency economy to form business policy and marketing plan of small and medium enterprises in Thailand," The Business review, vol. 13, no. 1, pp. 326-331, 2009.

[6] H. E. Stubbe, "Self-directed adult learning in a ubiquitous learning environment: A meta-review," CEUR Workshop Proceedings, pp. 5-28, vol. 349, 2009.

[7] M. S. Knowles, The modern practice of adult education: From pedagogy to andragogy, Englewood Cliffs: Prentice Hall, Cambridge, 1980.
[8] J. S. Brown. (2005). New Learning Environments for the 21st Century. [Online]. Available: http://www.johnseelybrown.com/newlearning.pdf

[9] P. Suppawan, "Development Competency-based Training Course basic level for sheet fed of offset printing technicial operetor in an organization," M.S. thesis, Dept. Printing and packaging technology. King Mongkut's University of Technology Thonburi, 2010.

[10] P. Khemkunasai "Views of Thai Muslim in southernmost provinces toward the government policy on cultural assimilation in southernmost provinces: strategies for solving problems," Journal of Taksinkadee, vol. 3, no. 2, pp. 73-82, 1993.

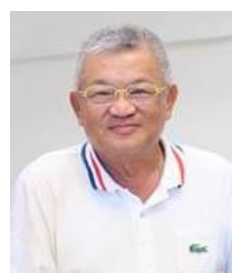

Anuchit Ngamkajonviwat is an Ed.D. candidate in the field of educational leadership and innovation, the Faculty of Education, Prince of Songkla University, Thailand.

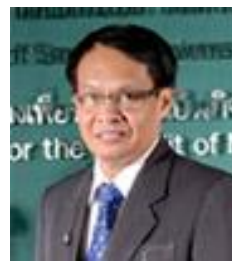

Wasant Atisabda is an assistant professor at the Department of Educational Technology, Faculty of Education, Prince of Songkla University, Thailand. $\mathrm{He}$ received a bachelor of education the field of teaching german as a second language and master of education in field of audio-visual education from Chulalongkorn University, Thailand, and a doctor of philosophy of higher and continuing education from

University of Missouri, USA.

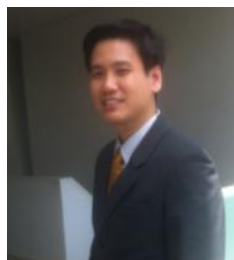

Ophat Kaosaiyaporn was born in Narathiwat, Thailand. He received a bachelor of education in the field of art education and master of education in the field of educational technology and communications from Prince of Songkla University, Thailand, and a doctor of philosophy of educational communications and technology from Chulalongkorn University, Thailand. $\mathrm{He}$ is a lecturer at the Department of Educational Technology, the faculty of education, Prince of Songkla University, Thailand.

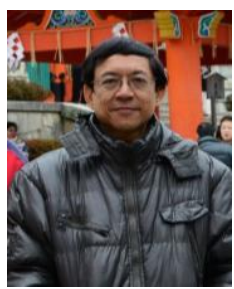

Chidchanok Choengchao is an associate professor at the Department of Educational Research and Evaluation Faculty of Education, Prince of Songkla University, Thailand. 